Berkala Ilmu Perpustakaan dan Informasi, Vol. 14, No. 1, Juni 2018, Hal. 95-107 DOI: $10.22146 /$ bip.27498

ISSN 1693-7740 (Print), ISSN 2477-0361 (Online)

Tersedia online di https://jurnal.ugm.ac.id/bip

\title{
Pengaruh pendidikan dan pelatihan terhadap kinerja pustakawan Universitas Gadjah Mada
}

\author{
Sarwono ${ }^{1}$, Wiyarsih ${ }^{1}$, dan Isbandini ${ }^{1}$ \\ ${ }^{1}$ Perpustakaan Universitas Gadjah Mada \\ Email: sarwana_lib@ugm.ac.id
}

Naskah diterima: 15 Agustus 2017, direvisi: 13 September 2017, disetujui: 17 Oktober 2017

\begin{abstract}
ABSTRAK
Pendahuluan.Tujuan penelitian ini adalah untuk mengetahui pengaruh pendidikan dan pelatihan (diklat) terhadap kinerja pustakawan Universitas Gadjah Mada. Tujuan penelitian ini adalah untuk mengetahui pengaruh pendidikan dan pelatihan terhadap kinerja pustakawan Universitas Gadjah Mada. Hal ini penting untuk dilakukan mengingat perpustakaan Universitas Gadjah Mada setiap tahun diselenggarakan pendidikan dan pelatihan.

Metode. Penelitian ini termasuk dalam penelitian eksplanasi (kuantitatif) dengan pendekatan survei (survey research). Teknik pengambilan sampel menggunakan metode sensus. Sedangkan pengambilan data menggunakan kuesioner dan dokumentasi. Subjek penelitian pustakawan UGM dan objek penelitian yakni diklat dan kinerja pustakawan UGM.

Data Analisis. Data dianalisa dengan menggunakan teknik SPSS.

Hasil dan Pembahasan. Analisis data menunjukkan bahwa mayoritas pustakawan UGM berpendidikan sarjana sejumlah 28 orang $(37,8 \%)$ dan terbanyak kedua berpendidikan magister yaitu sejumlah 21 orang $(28,4 \%)$. Pustakawan UGM yang pernah mengikuti pelatihan tentang pengetahuan umum lebih dari 5 kali adalah 19 pustakawan $(25,7 \%)$ dan pustakawan yang mengikuti pelatihan kepustakawanan lebih dari 5 sejumlah $6(8,1 \%)$. Kesimpulan. Skor kinerja pustakawan UGM berada dalam interval 56\%-75\% sehingga menunjukkan bahwa kinerja pustakawan UGM dalam kategori cukup baik. Diklat bidang pengetahuan umum memberikan pengaruh positif terhadap kinerja pustakawan UGM jika diberikan sebanyak 2-3 kali dalam setahun. Diklat bidang kepustakawanan memberikan pengaruh positif terhadap kinerja pustakawan UGM. Semakin banyak pendidikan dan pelatihan kepustakawanan yang diberikan maka kinerjanya semakin baik.
\end{abstract}

Kata kunci: Diklat; Pustakawan; Kinerja

\begin{abstract}
Introduction. This study aims to examine the role of education and training in influencing librarians' performance at the Main library of Universitas GadjahMada(UGM). The purpose of this study is to determine the effect of education and training on the performance of librarians of UGM is important to consider the library of UGM to organize education and trainin everyyear.

Data Collection Methods. This research used quantitative approach with survey. The subject of this study wais UGMlibrarian regarding their perspectives in the librarian traiing. Sample this research is 74 librarians.

Data Analysis. The data was analysed by usingSPSS

Results and Discussions. The results showed that library education did not affect the performance of librarians. General knowledge training affected the performance of librarians.

The performance of UGM librarians in the category is quite good. The data analysis shows that majority of UGM librarians have undergraduate education of 28 people (37.8\%) and the second most have master's degree which is 21 people $(28,4 \%)$. UGM librarians who have attended general knowledge training more than 5 times are 19 librarians (25.7\%) and librarians who follow librarian training of more than $56(8.1 \%)$. The performance score of UGM librarian is in interval of 56\%-75\% so it shows that the performance of UGMlibrarian in the category is quite good.
\end{abstract}


Conclusion. Training of general knowledge field give positive influence to the performance of UGM librarian if given as much as 2-3 times in a year. Training in the field of librarianship gives a positive influence on the performance of UGMlibrarians. The more training the librarianship is given the better the performance.

Keywords: Training; Librarian; Performance

\section{A. PENDAhULUAN}

Setiap perpustakaan selalu berusaha mencapai tujuan oragnisasi yang telah ditentukan. Untuk mencapai tujuan tersebut maka semua sumber daya yang dimiliki harus dimanfaatkan dengan sebaik-baiknya. Pustakawan sebagai sumber daya manusia perpustakaan adalah salah satu unsur penting yang harus dikembangkan oleh manajemen perpustakaan. Harapannya peran serta pustakawan semakin disadari arti pentingnya oleh pengelola perpustakaan dan universitas.

Upaya mempertahankan dan meningkatkan kinerja pustakawan maka manajemen perpustakaan maupun pimpinan universitas selalu berusaha untuk meningkatkan kualitas pustakawan. Agar pustakawan memiliki semangat kerja, berdedikasi, loyalitas dan sikap terpuji lainnya maka perlu direncanakan pendidikan dan pelatihan. Pendidikan dan pelatihan harus sesuai dengan bidang pekerjaan dan keadaan pustakawan yang akan melaksanakan tugas pada bidang tersebut. Meningkatkan pendidikan dapat ditempuh dengan memberikan kesempatan kepada pustakawan untuk melanjutkan studi ke jenjang yang lebih tinggi dengan memberikan beasiswa maupun biaya mandiri. Pelatihan dapat diberikan secara periodik dan terprogram. Pendidikan dan pelatihan yang dijalani oleh pustakawan diharapkan dapat meningkatkan kinerja pustakawan. Program pendidikan dan pelatihan penting untuk dilakukan dengan berbagai alasan, diantaranya karena adanya karyawan/pegawai baru, adanya alat-alat baru, ada sistem baru dan sebagainya. Pendidikan dan pelatihan merupakan salah satu faktor yang membentuk kinerja. Pendidikan dan pelatihan diharapkan dapat memberikan pengaruh positif terhadap perilaku pustakawan dalam menjalankan tugas. Pendidikan akan membentuk dan menambah pengetahuan serta wawasan pustakawan sehingga dapat membantu dalam melaksanakan tugas-tugas kesehariannya, sedangkan pelatihan akan membentuk dan meningkatkan ketrampilan pustakawan.

Pelaksanaan program pelatihan dapat dikatakan berhasil apabila dalam diri para peserta terjadi suatu proses transformasi dengan baik, apabila terjadi peningkatan kemampuan dalam melaksanakan tugas dan terjadi perubahan perilaku yang tercermin pada sikap, disiplin dan etos kerja. Keberhasilan program pelatihan sangat dipengaruhi oleh beberapa faktor antara lain motivasi (dorongan) dari diri sendiri, motivasi dari lingkungan organisasi/institusi perpustakaan serta motivasi dari atasan. Di samping itu faktor yang tak kalah penting adanya harapan yang timbul dari seorang pustakawan karena setelah mengikuti pelatihan dan meningkatnya prestasi kerja untuk memperoleh peningkatan karier atau untuk menduduki jabatan yang lebih tinggi.

Dalam kenyataannya masih terdapat pustakawan yang mendapatkan pendidikan dan pelatihan tetapi kinerjanya belum seperti yang diharapkan. Hal ini dapat disebabkan pendidikan dan pelatihan yang diselenggarakan tidak sesuai dengan kebutuhan pustakawan.

Menurut data kepegawaian Perpustakaan UGM tahun 2017, Perpustakaan UGM memiliki 82 orang pustakawan yang terdiri dari pustakawan ahli dan pustakawan terampil. Tim manajemen Perpustakaan UGM senantiasa menyelenggarakan pendidikan dan pelatihan bagi pustakawannya. Berbagai pelatihan yang diselenggarakan bertujuan untuk meningkatkan kinerja pustakawan UGM. Dengan demikian perlu diketahui apakah meningkatnya pendidikan dan pelatihan yang sudah diselenggarakan memberikan pengaruh terhadap kinerja pustakawan.

Berdasarkan uraian diatas, tujuan penelitian ini adalah untuk mengetahui pengaruh 
pendidikan dan pelatihan terhadap kinerja pustakawan Universitas Gadjah Mada

\section{B. TINJAUAN PUSTAKA Penelitian Terdahulu}

Boon dan Arumugam (2006) dalam Rasjid (2012) meneliti pengaruh budaya organisasi terhadap komitmen pegawai pada perusahaan. Pada studi tersebut pelatihan dan pengembangan merupakan salah satu dimensi budaya organisasi, bersama-sama dengan dimensi imbalan dan penghargaan, serta kerja sama tim, diuji pengaruhnya terhadap komitmen pegawai. Penelitian ini dilakukan pada pegawai di Industri semikonduktor di Malaysia dan dapat diketahui bahwa pelatihan dan pengembangan, terbukti memiliki pengaruh positif signifikan terhadap komitmen pegawai.

Defril (2005) menyampaikan dalam penelitiannya bahwa hasil analisis korelasi menunjukkan bahwa hubungan antara variabel profesionalisme dan variabel pendidikan dan pelatihan mempunyai korelasi positif sebesar 0,426 dengan katergori tingkat keeratan korelasi sedang.

Sulistio (2009) menyatakan dalam penelitiannya bahwa pendidikan dan pelatihan fungsional penjenjangan perencana berpengaruh positif terhadap kinerja pejabat fungsional perencana.

Penelitian Rasjid (2012) menyatakan bahwa Pendidikan dan pelatihan berpengaruh positif dan signifikan terhadap kinerja anggota DPRD Kabupaten Purworejo Pemilu 2009. Menurut Deming dalam Dessler (2006) kinerja merupakan fungsi dari pelatihan, komunikasi, alat, dan pengawasan. Pendidikan dan pelatihan diharapkan dapat memberikan perbaikan terhadap perilaku pegawai dalam bekerja. Hal ini sesuai dengan pernyataan Sulistiyani dan Rosidah (2003) bahwa salah satu cara yang dapat dilakukan dalam upaya meningkatkan kinerja pegawai adalah dengan pengembangan melalui pendidikan dan pelatihan.

\section{Pendidikan dan Pelatihan}

Martoyo (1994) mengungkapkan bahwa pendidikan adalah proses pengembangan sumber daya manusia. Menurut Widjaya (1995) pendidikan dimaksudkan untuk membina dan mengembangkan kemampuan berpikir para pegawai, meningkatkan kemampuan mengeluarkan gagasan para pegawai, agar mereka dapat menjalankan tugas kewajibannya dengan sebaik-baiknya. Dari pendapat tersebut dapat disimpulkan bahwa pendidikan adalah upaya yang dilakukan guna meningkatkan kemampuan sumber daya manusia.

Pendidikan adalah suatu proses dalam rangka mempengaruhi peserta didik supaya mampu menyesuaikan diri sebaik mungkin dengan lingkungannya (Hamalik, 2008). Hasil dari proses pendidikan adalah adanya perubahan dalam diri individu yang memungkinkannya untuk berfungsi lebih baik dalam kehidupan bermasyarakat. Pembelajaran dilakukan untuk mengarahkan proses pendidikan agar sasaran dari perubahan yang akan dicapai dapat terlaksana sesuai dengan tujuan yang telah ditentukan.

Setelah mengetahui definisi dari pendidikan, selanjutnya perlu dipahami pengertian pendidikan formal menurut Peraturan Pemerintah Republik Indonesia Nomor 66 Tahun 2010 tentang Pengelolaan dan Penyelenggaraan Pendidikan adalah jalur pendidikan yang terstruktur dan berjenjang yang terdiri atas pendidikan dasar, pendidikan menengah, dan pendidikan tinggi. Pendidikan dasar kita kenal dengan sekolah dasar, pendidikan menengah kita kenal dengan sekolah menengah pertama dan sekolah menengah atas atau sekolah menengah kejuruan. Pendidikan tinggi diperoleh dari berbagai jenis perguruan tinggi seperti universitas, institut, akademi dan sekolah tinggi.

Berbeda dengan pendidikan, pelatihan merupakan suatu kegiatan yang dilaksanakan oleh suatu organisasi atau perusahaan untuk meningkatkan kecakapan, keahlian, dan meningkatkan pengetahuan para pegawainya guna pencapaian tujuan organisasi atau perusahaan. Wursanto (1989) mengatakan bahwa pelatihan adalah suatu proses kegiatan yang dilakukan oleh manajemen kepegawaian dalam rangka meningkatkan pengetahuan, kecakapan, keterampilan, keahlian dan mental para pegawai dalam melaksanakan tugas dan 
pekerjaannya. Pelatihan lebih mengembangkan keterampilan teknis, sehingga pegawai dapat menjalankan pekerjaan sebaik-baiknya. Latihan berhubungan langsung dengan pengajaran tugas pekerjaan (Widjaja, 1995).

\section{Kinerja}

Dharma (2005) menyatakan bahwa "kinerja adalah suatu cara untuk mendapatkan hasil yang lebih baik bagi organisasi, kelompok dan individu dengan memahami dan mengelola kinerja sesuai dengan target yang direncanakan, standar dan persyaratan kompetensi yang telah ditentukan. Definisi di atas mengandung unsurunsur penting sebagai berikut: suatu kerangka kerja dari sasaran yang telah direncanakan, standar dan persyaratan kompetensi yang telah disepakati, kinerja merupakan serangkaian tindakan yang diambil untuk mencapai suatu hasil dari hari ke hari dan mengelola peningkatan kinerja diri mereka sendiri maupun orang lain, pemahaman bersama bahwa untuk memperbaiki kinerja, para individu perlu memiliki pemahaman bersama tentang bagaimana seharusnya bentuk tingkat kinerja dan kompetensi yang tinggi dan faktor yang hendak dicapai. Suatu pendekatan dalam mengelola dan mengembangkan sumber daya manusia. Kinerja berfokus pada tiga hal. Pertama, bagaimana para manajer dan pemimpin kelompok bekerja secara efektif dengan orang-orang di sekitar mereka. Kedua, bagaimana para individu bekerjasama dengan para manajer dan kelompok. Ketiga, bagaimana individu dapat dikembangkan untuk meningkatkan pengetahuan, keahlian dan kepiawaian mereka dan tingkat kompetensi serta kinerja mereka."

Kinerja berasal dari pengertian performance (Wibowo, 2016). Ada pula yang memberikan pengertian performance sebagai hasil kerja atau prestasi kerja. Kinerja tidak saja bermakna sebagai hasil kerja tetapi bagaimana proses pekerjaan berlangsung. Lebih lanjut Wibowo (2016) mengatakan kinerja merupakan hasil pekerjaan yang mempunyai hubungan kuat dengan tujuan strategis organisasi, kepuasan konsumen, dan memberikan kontribusi pada ekonomi. Dengan demikian kinerja adalah tentang melakukan pekerjaan dan hasil yang dicapai dari pekerjaan tersebut. Kinerja adalah tentang apa yang dikerjakan dan bagaimana cara mengerjakannya.

Menurut Mangkunegara (2005) untuk mencapai kinerja yang diharapkan dalam suatu organisasi atau instansi, para pegawai harus mendapatkan program pendidikan dan pelatihan yang memadai untuk jabatannya sehingga pegawai terampil dalam melaksanakan pekerjaannya.

\section{METODE PENELITIAN}

Penelitian ini termasuk dalam penelitian kuantitatif. Berdasarkan tingkat eksplanasinya penelitian ini termasuk ke dalam penelitian dengan pendekatan survei (survey research). Penelitian survei yaitu penelitian yang dilakukan terhadap seluruh unit penelitian dalam populasi. Penelitian survei bertujuan mendiskripsikan kejadian relatif, distribusi dan hubungan antar variabel yang terjadi secara alami (Hartinah, 2013).

Penelitian ini dilakukan di Perpustakaan UGM dalam kurun waktu dua setengah bulan, yaitu $1 \mathrm{Mei}-15$ Juli 2017. Subjek penelitian ini pustakawan UGM. Adapun objek yang diteliti yakni pendidikan dan pelatihan pustakawan UGM, serta pengaruhnya terhadap kinerja pustakawan UGM.

Populasi pada penelitian ini seluruh pustakawan UGM yang berjumlah 82 orang. Tiga orang pustakawan sebagai peneliti dalam penelitian ini sehingga populasi pustakawan UGM berjumlah 79. Lima orang pustakawan tidak bersedia menjadi responden.

Teknik pengambilan sampel yang digunakan pada penelitian ini adalah metode sensus mengingat jumlah populasi penelitian relatif kecil. Melalui metode ini seluruh pustakawan UGM menjadi sampel pada penelitian ini.

Untuk mengkaji adanya pengaruh pendidikan dan pelatihan terhadap kinerja pustakawan UGM dalam penelitian ini, maka variabel dibagi menjadi dua jenis yaitu variabel pendidikan dan pelatihan sebagai variabel bebas dan kinerja sebagai variabel terikat. 
Untuk memberi kejelasan mengenai arah penelitian ini maka diberikan batasan-batasan operasional terhadap variabel-variabel penelitian. Untuk menghindari penafsiran yang berbeda terhadap masalah dalam penelitian ini, diperlukan penegasan istilah pada masingmasing variabel penelitian sebagai berikut:

Variabel bebas (Independen).

Variabel ini terdiri dari dua variabel yaitu pendidikan dan pelatihan. Masing-masing variabel diuraikan sebagai berikut:

a. Pendidikan.

Yang dimaksud dengan pendidikan adalah upaya yang dilakukan guna meningkatkan kemampuan sumber daya manusia. Pendidikan adalah proses yang dilakukan untuk membina kemampuan atau mengembangkan kemampuan berfikir para pegawai serta meningkatkan kemampuan mengeluarkan gagasan-gagasan para pegawai. Sehingga mereka dapat menunaikan tugas kewajibannya dengan sebaik-baiknya. Indikator pendidikan yang digunakan pada variabel ini adalah tingkat pendidikan formal.

\section{b. Pelatihan}

Pelatihan adalah suatu proses kegiatan yang dilakukan oleh manajemen kepegawaian dalam rangka meningkatkan pengetahuan, kecakapan, ketrampilan, keahlian dan mental para pegawai/pustakawan dalam melaksanakan tugas dan pekerjaannya. Pelatihan berbeda dengan pendidikan, pelatihan lebih mengembangkan ketrampilan teknis, sehingga pegawai/pustakawan dapat menjalankan pekerjaan sebaik-baiknya. Indikator yang digunakan pada variabel ini adalah:

- frekuensi mengikuti pelatihan sesuai bidang tugas

- frekuensi mengikuti pelatihan di luar bidang tugas

\section{Variabel Terikat (Dependen)}

Variabel terikat merupakan variabel yang dipengaruhi oleh variabel bebas. Variabel terikat pada penelitian ini yakni kinerja. Kinerja merupakan hasil kerja secara kualitas dan kuantitas yang dicapai oleh seseorang dalam melaksanakan tugasnya sesuai dengan tanggungjawab yang diberikan kepadanya. Kinerja juga dapat dikatakan sebagai hasil kerja yang dapat dicapai oleh seseorang atau sekelompok orang dalam suatu organisasi, sesuai dengan wewenang dan tanggung jawab masing-masing.

Langkah awal peneliti mengumpulkan data langsung (data primer) dari responden melalui kuesioner. Data sekunder yang dikumpulkan antara lain berupa data mengenai jumlah pustakawan UGM.

Metode pengumpulan data yang digunakan dalam penelitian ini yakni kuesioner dan dokumentasi. Kuesioner ini dimaksudkan untuk memperoleh data mengenai pendidikan, pelatihan dan kinerja pustakawan UGM. Dokumentasi dalam penelitian ini berupa memo atau dalam bentuk peraturan-peraturan tertulis dari instansi yang bersangkutan dengan objek penelitian dan sumber-sumber lain untuk mendapatkan teori yang mendukung penelitian ini.

Instrumen yang digunakan pada penelitian ini adalah berupa kuesioner. Kuesioner ini digunakan untuk memperoleh data kuantitatif mengenai variabel-variabel pada penelitian ini, yaitu pendidikan (X1), pelatihan non kepustakawanan (X2), pelatihan bidang kepustakawanan (X3) dan kinerja (Y). Variabel yang akan diteliti ini akan diukur dengan skala interval. Skala interval adalah ukuran yang tidak semata-mata menunjukkan urutan (rangking) objek penelitian berdasarkan suatu atribut, tetapi juga memberikan informasi tentang jarak perbedaan (interval) antara tingkatan objek yang satu dengan tingkatan objek yang lain.

Adapun skor tiap jawaban dari setiap pertanyaan atau pernyataan mempunyai gradasi dari yang paling kecil hingga paling besar dapat dilihat pada Tabel 1 .

Dari 74 kuesioner yang terkumpul, diambil 30 responden untuk uji validitas. Akan tetapi, karena keterbatasan responden maka 30 responden untuk uji validitas ini sekaligus merupakan responden penelitian. Dengan demikian, responden hanya mengisi kuesioner satu kali, sehingga bias pengisian kuesioner dapat dihindari. 
Berdasarkan hasil analisis validitas, dari 12 pernyataan terdapat 3 pernyataan yang dinyatakan gugur sehingga pernyataa kinerja hanya memuat 9 pernyataan.

Uji reliabilitas dilakukan dengan Alpha Cronbach. Hasil uji reliabilitas didapatkan nilai alpha cronbach sebesar 0,787 . Nilai ini lebih besar dari nilai kritis sebesar 0,63 sehingga kuesioner dinyatakan reliabel.

\section{HASIL DAN PEMBAHASAN Deskripsi subyek penelitian}

1. Deskripsi subjek penelitian berdasarkan jenjang jabatan

Pustakawan UGM terdiri dari beberapa jenjang pustakawan seperti yang dapat dilihat pada Tabel 2.

Berdasarkan Tabel 2 dapat dilihat bahwa jenjang pustakawan UGM sangat beragam dengan persentase terbesar ada pada jenjang jabatan pustakawan pertama, yakni 22 orang (29,7\%). Pustakawan keahlian berjumlah 45 orang $(60,8 \%)$ dan pustakawan ketrampilan berjumlah 29 orang $(39,2 \%)$.

2. Deskripsi subyek penelitian berdasarkan jenis kelamin (Tabel 3)

Hasil penelitian menunjukkan bahwa mayoritas pustakawan UGM yakni perempuan sejumlah $60,8 \%$ dan laki-laki sebanyak $39,2 \%$.

\section{Analisis data}

\section{a. Deskripsi Variabel Penelitian}

Variabel pada penelitian ini terdiri dari $3 \mathrm{sub}$ variabel bebas dan 1 variabel terikat. Sub variabel bebas pada penelitian ini adalah pendidikan, pelatihan umum dan pelatihan kepustakawanan. Sedangkan variabel terikatnya yakni kinerja. Variabel pendidikan diukur berdasarkan pendidikan formal yang dimiliki pustakawan UGM. Adapun yang dimaksud dengan analisis deskriptif dan atau tabulasi data merupakan hasil dokumentasi dan kuesioner mengenai pendidikan, pelatihan dan kinerja. Sedangkan analisis data deskriptif dilakukan untuk mengetahui tingkat pendidikan, pelatihan dan kinerja pustakawan UGM.

\section{Pendidikan}

Latar belakang pendidikan Pustakawan UGM berbeda-beda. Pendidikan terendah yang dimiliki pustakawan UGM yakni SLTA/sederajat. Sedangkan pendidikan tertinggi pustakawan UGM yakni Doktor (S-3). Proporsi dari masing-masing jenjang pendidikan pustakawan UGM dapat dilihat dari Tabel 4 yang menunjukkan secara lengkap jenjang pendidikan pustakawan UGM.

Berdasarkan Tabel 4 menunjukkan bahwa mayoritas pustakawan UGM berlatar belakang pendidikan sarjana (S-1) 37, 8\%. Selanjutnya pustakawan berlatar belakang pendidikan magister (S-2) berjumlah 28,4\%.

\section{Pelatihan}

Pelatihan terhadap pustakawan UGM diteliti melalui 2 item kuesioner dengan 4 pilihan jawaban. Pelatihan dibedakan menjadi dua yaitu pelatihan mengenai pengetahuan umum dan pelatihan mengenai kepustakawanan. Tabel 5 menunjukkan frekuensi pelatihan pengetahuan umum yang telah diikuti oleh pustakawan UGM.

Berdasarkan tabel 5 dapat diketahui bahwa pustakawan UGM yang mengikuti pelatihan tentang pengetahuan umum lebih dari 5 kali 25, 7\%, mengikuti 4-5 kali 35\%, mengikuti $2-3$ kali $22,9 \%$ dan yang mengikuti 0 1 kali 16,4\%. Mayoritas pustakawan telah mengikuti 4-5 kali pelatihan dalam bidang pengetahuan umum $35 \%$.

Tabel 6 di bawah ini memberikan gambaran tentang jumlah pelatihan kepustakawan yang telah diikutimoleh pustakawan UGM.

Hasil penelitian menunjukkan bahwa pustakawan UGM yang mengikuti pelatihan tentang kepustakawanan lebih dari 5 kali $8,1 \%$, mengikuti 4-5 kali 40,5\%, mengikuti 2-3 kali $31,1 \%$ dan yang mengikuti $0-1$ kali $20,3 \%$. Mayoritas pustakawan telah mengikuti 4-5 kali pelatihan dalam bidang kepustakawanan $40,5 \%$.

\section{Kinerja}

Secara rinci, kinerja dapat dilihat dari distribusi frekuensi pada masing-masing indikator kinerja sebagai berikut: 
a. Distribusi frekuensi pustakawan dalam mengkaji tugas pokok

Berdasarkan hasil penelitian tersebut dapat diketahui bahwa 47,3\% pustakawan memilih kategori "kadang-kadang" dalam bidang pengkajian tugas pokok. Untuk itu diupayakan agar pustakawan melakukan pengkajian tugas pokok misalnya dengan mengikuti pelatihan, workshop dan hibah kompetisi.

b. Distribusi frekuensi pustakawan dalam mendiskusikan tugas pokok dengan sesama

Berdasarkan hasil penelitian diketahui bahwa 47,3\% pustakawan dalam kategori "kadang-kadang" dalam mendiskusikan tugas pokoknya dengan sesama pustakawan diikuti dengan pustakawan yang sering mendiskusikan tugas pokoknya dengan sesama pustakawan. Untuk itu perlu ditingkatkan yakni dengan melakukan sharing melalui berbagai media baik langsung maupun tidak langsung. Sharing tentang tugas pokok sangat penting dilakukan pustakawan untuk memecahkan berbagai masalah maupun dalam meningkatkan kualitas tugas pokoknya.

c. Distribusi frekuensi pustakawan dalam memberikan tanggapan mengenai tugas pokok yang sudah ditetapkan

Berdasarkan hasil penelitian diketahui bahwa $58,1 \%$ pustakawan memilih kategori "kadang-kadang" dalam memberikan tanggapan mengenai tugas pokok. Hal ini memberikan arti bahwa kinerja pustakawan dalam memberikan tanggapan mengenai tugas pokok masih perlu ditingkatkan dengan melalui berbagai cara baik secara langsung maupun melalui media.

d. Distribusi frekuensi pustakawan dalam mendiskusikan tugas pokok dan fungsi kepustakawanan masing-masing dengan atasannya

Berdasarkan hasil penelitian diketahui bahwa 70,3\% pustakawan memilih kategori "kadang-kadang" dalam mendiskusikan tugas pokok dan fungsinya kepada atasannya. Untuk itu kinerja pustakawan dalam mendiskusikan tugas pokok dan fungsi kepada atasan masih perlu ditingkatkan, misalnya dengan adanya komunikasi dan keterbukaan kepada atasannya apabila ada masalah.

e. Distribusi frekuensi peran pustakawan dalam mengajukan perubahan tugas pokok masing-masing pada saat pembahasan

Berdasarkan hasil penelitian diketahui bahwa 48,6\% pustakawan memilih kategori "kadang-kadang" dalam mengajukan perubahan tugas pokok pada saat pembahasan. Untuk itu kinerja pustakawan dalam mengajukan perubahan tugas pokok pada saat pembahasan masih perlu ditingkatkan. Pustakawan hendaknya aktif mengajukan perubahan tugas pokokagar mempunyai berbagai kompetensi di berbagai bidang.

f. Distribusi frekuensi pustakawan dalam melakukan dialog langsung dengan pemustaka yang dilayani

Berdasarkan hasil penelitian diketahui bahwa 56,8\% memilih kategori "sering" melakukan dialog langsung dengan pemustaka yang dilayani. Pustakawan sering melakukan dialog dengan pemustaka maka akan terjalin komunikasi dengan pemustaka sehingga mengetahui apa yang dibutuhkan dan dikehendaki oleh pemustaka.

g. Distribusi frekuensi pustakawan dalam berkunjung ke unit lain untuk memperoleh masukan tentang tugas pokok dan fungsinya

Berdasarkan hasil penelitian di atas dapat diketahui bahwa 59,5\% pustakawan memilih kategori "kadang-kadang" dalam berkunjung ke unit lain untuk memperoleh masukan tentang tugas pokok dan fungsinya. Untuk itu frekuensi pustakawan dalam berkunjung ke unit lain untuk memperoleh masukan tentang tugas pokok dan fungsi masih perlu ditingkatkan. Kegiatan ini sangat penting dilakukan pustakawan untuk saling sharing informasi tentang tugas pokok dan fungsi pustakawan sehingga diperoleh tambahan wawasan dan pengetahuan untuk meningkatkan kinerjanya.

h. Distribusi frekuensi pustakawan dalam mengajak kerjasama dengan organisasi profesi untuk memperoleh berbagai macam masukan pustakawan lain/organisasi profesi 
Berdasakan hasil penelitian diketahui bahwa $66,2 \%$ pustakawan memilih kategori "kadang-kadang" dalam mengajak kerjasama dengan pustakawan lain/organisasi profesi untuk memperoleh berbagai masukan. Untuk itu perlu ditingkatn karena kegiatan ini sangat penting dilakukan pustakawan agar pekerjaan yang dirasa berat dapat dilakukan lebih mudah dan ringan. Kerja sama juga dapat meningkatkan kinerja baik secara pribadi maupun bersama-sama.

i. Distribusi frekuensi pustakawan dalam menyampaikan aspirasi atau masukan dari masyarakat/pemustaka dalam berbagai kesempatan atau rapat

Berdasarkan hasil penelitian di atas dapat diketahui bahwa 47,3\% pustakawan memilih kategori "sering" dalam menyampaikan aspirasi atau masukan dari masyarakat/pemustaka dalam berbagai kesempatan atau rapat. Walaupun begitu, kegiatan tersebut masih perlu ditingkatkan. Pustakawan hendaknya selalu menyampaikan berbagai aspirasi dari pemustaka dalam berbagai kesempatan untuk memenuhi kebutuhan pemustaka.

\section{j. Distribusi frekuensi peran aktif pustakawan dalam implementasi penggunaan anggaran yang sudah ditetapkan}

Berdasarkan hasil penelitian dapat diketahui bahwa 50,0\% pustakawan memilih kategori "kadang-kadang" dalam berperan aktif implementasi penggunaan anggaran yang sudah ditetapkan. Pustakawan hendaknya selalu berperan aktif dalam implementasi penggunaan anggaran yang sudah ditetapkan. Dengan demikian anggaran yang sudah ditetapkan dapat dimanfaatkan secara maksimal.

\section{k. Distribusi frekuensi data tentang ketepatan waktu pustakawan dalam kenaikan pangkat dan atau jabatan sesuai ketentuan}

Berdasarkan hasil analisis di atas dapat diketahui bahwa 59,5\% pustakawan memilih kategori "kadang-kadang" dalam ketepatan waktu kenaikan pangkat dan atau jabatan sesuai ketentuan. Untuk itu pustakawan hendaknya selalu tepat waktu dalam kenaikan pangkat dan atau jabatan sesuai ketentuan. Dengan demikian maka karier pustakawan akan lancar untuk mencapai jenjang yang lebih tinggi.

\section{l. Distribusi frekuensi pustakawan dalam menghasilkan karya tulis setiap tahunnya}

Berdasarkan hasil penelitian di atas dapat diketahui bahwa $75,7 \%$ pustakawan memilih kategori "kadang-kadang" dalam menghasilkan karya tulis setiap tahunnya. Pustakawan hendaknya selalu menghasilkan karya tulis setiap tahunnya. Hal ini selain untuk pengembangan diri juga dapat memudahkan dalam perolehan angka kredit dan sekaligus memperlancar kenaikan pangkat dan atau jabatannya.

Secara keseluruhan, frekuensi terbesar dari setiap item pada masing-masing indikator diperlihatkan dalam Tabel 7.

Berdasarkan Tabel 7 dapat diketahui bahwa 8 indikator dalam katagori "kadang-kadang". Ada 2 indikator dalam kategori "sering" yaitu pada indikator frekuensi pustakawan dalam melakukan dialog langsung dengan pemustaka yang dilayani yaitu sebesar $56,8 \%$ dan yang kedua pada indikator frekuensi pustakawan dalam menyampaikan aspirasi atau masukan dari masyarakat/pemustaka dalam berbagai kesempatan atau rapat sebesar $47,3 \%$.

Menurut Arikunto (2010) pengetahuan seseorang dapat diketahui dan diinterpretasikan dengan skala yang bersifat kualitatif, yaitu :

1) Baik: Hasil persentase $76 \%-100 \%$

2) Cukup: Hasil persentase $56 \%-75 \%$

3) Kurang: Hasil persentase $<56 \%$

Berdasarkan skor di atas maka interval kategori analisis deskriptifnya dapat dilihat pada Tabel 8.

Berdasarkan hasil tabulasi jawaban pustakawan UGM terhadap variabel kinerja secara keseluruhan diketahui bahwa total skor sebesar 1817 atau sebesar 68,2\%. Apabila dikonfirmasikan dengan tabel interval di atas dapat diketahui bahwa skor kinerja pustakawan UGM berada dalam interval 56\%-75\% dengan kategori cukup baik. Dengan demikian dapat dikatakan bahwa kinerja pustakawan UGM cukup baik. 


\section{b. Hubungan Pendidikan dan Pelatihan dengan Kinerja}

Hubungan Pendidikan dan pelatihan dengan kinerja maka dilakukan uji korelasi dengan uji korelasi Spearman karena data yang tersedia merupakan data interval. Pengambilan kesimpulan dilakukan dengan melihat nilai $\mathrm{P}$. Nilai $\mathrm{P}<0.05$ maka Ha diterima yang artinya terdapathubungan.

Berdasarkan hasil analisis (Tabel 9) diketahui hanya variabel pelatihan di luar bidang tugas yang mempunyai nilai $\mathrm{P}<0,05$ sehingga dapat disimpulkan bahwa pelatihan di luar bidang tugas berpengaruh pada kinerja, sedangkan dua variabel yang lain tidak berpengaruh. Artinya ada hubungan antara pelatihan bidang pengetahuan umum dengan kinerja pustakawan UGM sebagaimana terlihat dalam Tabel 9.

Data Tabel 9 menunjukkan bahwa pustakawan UGM berpendidikan SLTA yang memiliki kinerja baik $0 \%$, berkinerja cukup $75 \%$ dan berkinerja kurang 25\%. Pustakawan UGM berpendidikan diploma yang memiliki kinerja baik $15 \%$, berkinerja cukup $55 \%$ dan berkinerja kurang 30\%. Pustakawan UGM berpendidikan S-1 yang berkinerja baik 7,1\%, berkinerja cukup 71,4\% dan berkinerja kurang 21,4 \%. Pustakawan UGM berpendidikan S-2 berkinerja baik $4,8 \%$, berkinerja cukup $71,4 \%$ dan berkinerja kurang 23,8\%. Pustakawan UGM berpendidikan S-3 100\% berkinerja baik.

Dapat diketahui bahwa bahwa pustakawan UGM berkinerja cukup memiliki prosentase yang paling banyak untuk pendidikan SLTA, S1 dan S-2. Sehingga dapat diambil kesimpulan bahwa pendidikan tidak memiliki pengaruh yang signifikan terhadap kinerja. Hal ini sesuai dengan tingkat signifikansi (P) yang ditunjukkan dalam tabel yaitu sebesar 0,708 yang berarti tidak ada hubungan karena $\mathrm{P}>0,05$.

Tabel 9 juga memperlihatkan bahwa pustakawan UGM yang mengikuti pelatihan diluar bidang tugas (pengetahuan umum) lebih dari 5 kali memiliki kinerja baik 5,3\%, berkinerja cukup $68,4 \%$ dan berkinerja kurang $26,3 \%$. Pustakawan UGM yang mengikuti pelatihan diluar bidang tugas 4-5 kali memiliki kinerja baik sejumlah 3,8\%, berkinerja cukup
$50 \%$ dan berkinerja kurang $46,2 \%$. Pustakawan UGM yang mengikuti pelatihan diluar bidang tugas 2-3 kali memiliki kinerja baik 11,8\%, berkinerja cukup $82,4 \%$ dan kinerja kurang $5,9 \%$. Pustakawan UGM yang mengikuti $0-1$ kali pelatihan diluar bidang tugas memiliki kinerja baik $25 \%$, berkinerja cukup sejumlah $75 \%$.

Berdasarkan hasil di atas pustakawan UGM yang mengikuti pelatihan diluar bidang tugasnya 2-3 kali dan 0-1 kali memiliki kinerja yang lebih baik daripada pustakawan UGM yang mengikuti pelatihan diluar bidang 4-5 kali dan lebih dari 5 kali. Pelatihan 2-3 kali mendapat persentase terbesar $(82,4 \%)$ dalam kategori kinerja cukup baik.

Tabel 9 juga menunjukkan bahwa pustakawan UGM yang mengikuti pelatihan kepustakawanan yang sesuai bidang tugas 4-5 kali ternyata hanya $6,7 \%$ yang berkinerja baik dan $63.3 \%$ yang berkinerja cukup baik, serta $30 \%$ yang berkinerja kurang baik. Sementara itu pustakawan UGM yang mengikuti pelatihan kepustakawanan/sesuai bidang tugas 0-1 kali terdapat $26,7 \%$ pustakawan UGM berkinerja baik dan $60,0 \%$ yang berkinerja cukup baik serta $13,3 \%$ yang berkinerja kurang baik. Pelatihan lebih dari 5 kali mendapat persentase terbesar $(83,3 \%)$ dalam kategori kinerja cukup baik.

\section{E. KESIMPULAN}

Penelitian ini menghasilkan beberapa kesimpulan, yaitu kinerja pustakawan UGM dalam kategori cukup baik $68,2 \%$, Pendidikan dan pelatihan (diklat) di luar bidang tugas sebanyak 2-3 kali dalam setahun mendapat persentase terbesar $82,4 \%$ dalam kategori kinerja cukup baik. Diklat lebih dari 5 kali dalam setahun mendapat prosentase terbesar $83,3 \%$ dalam kategori kinerja cukup baik, Diklat bidang pengetahuan umum memberikan pengaruh positif terhadap kinerja pustakawan UGM jika diberikan sebanyak 2-3 kali dalam setahun, Diklat bidang kepustakawanan memberikan pengaruh positif terhadap kinerja pustakawan UGM. Semakin banyak pelatihan kepustakawanan yang diberikan maka kinerjanya semakin baik. 
Berkaitan dengan kesimpulan di atas maka direkomendasikan untuk diklat pengetahuan umum diselenggarakan 2-3 kali setiap tahunnya agar memberikan dampak positif terhadap kinerja pustakawan UGM. Apabila jumlah pelatihan tersebut lebih dari 3 kali dimungkinkan akan mengganggu kinerja pustakawan. Sedangkan pelatihan kepustakawanan diselenggarakan minimal 5 kali dalam setahun agar dapat mendukung kinerja pustakawan UGM.

\section{DAFTAR PUSTAKA}

Defril. (2005). Pengaruh pendidikan dan pelatihan terhadap profesionalisme aparatur pemerintah daerah di Kabupaten Kepulauan Riau. Yogyakarta: Program Pasca Sarjana UGM

Dessler, G., (2006). Manajemen sumber daya manusia. New Jersey: Prentice Hall.

Dharma, Surya. (2005). Manajemen kinerja falsafah teori dan penerapannya. Yogyakarta: Pustaka Pelajar.

Hartinah, Sri. (2013). Metode penelitian perpustakaan. Jakarta: Universitas Terbuka
Mangkunegara, A. P., (2005). Kualitas Kinerja Pegawai. Jakarta: Ghalia Indonesia.

Martoyo, Susilo. (1994). Manajemen sumber daya manusia. Yogyakarta: BPFE UGM.

Rasjid, M.A. (2012). Pengaruh pendidikan dan pelatihan terhadap kinerja (performance) anggota Dewan Perwakilan Rakyat Daerah Pemilu 2009 Kabupaten Purworejo. Yogyakarta: Program Pasca Sarjana UGM

Sulistio, D., (2009). Pengaruh pendidikan dan pelatihan fungsional penjenjangan perencana terhadap kompetensi dan kinerja pejabat fungsional perencana. Yogyakarta: Program Pasca Sarjana UGM.

Sulistiyani, A. T. \& Rosidah. (2003). Manajemen sumber daya manusia. Yogyakarta: Graha Ilmu.

Wibowo. (2016). Manajemen kinerja. Jakarta: Raja Grafindo Persada

Widjaja, A.W. (1995). Administrasi kepegawaian. Jakarta: Raja Grafindo Persada.

Wursanto. 1989. Manajemen kepegawaian. Yogyakarta: Kanisius 


\section{DAFTAR TABEL}

Tabel 1. Skor Pengukuran Variabel.

\begin{tabular}{lc}
\hline \multicolumn{1}{c}{ Jawaban } & Skor \\
\hline Selalu & 4 \\
Sering & 3 \\
Kadang-kadang & 2 \\
Tidak pernah & 1 \\
\hline
\end{tabular}

Tabel 2. Jenjang Jabatan Pustakawan UGM

\begin{tabular}{clc}
\hline No Jabatan & Jumlah \\
\hline 1 & Pustakawan Keahlian & \\
a & Pustakawan Madya & 7 \\
b & Pustakawan Muda & 16 \\
c & Pustakawan Pertama & 22 \\
2 & Pustakawan Ketrampilan & \\
& Pustakawan Penyelia & 8 \\
& Pustakawan Pelaksana Lanjutan & 14 \\
& Pustakawan Pelaksana & 7 \\
& Total Jumlah & 74 \\
\hline Sumber: Data Kepegawaian Perpustakaan UGM Tahun 2017
\end{tabular}

Tabel 3. Pustakawan UGM Berdasarkan Jenis Kelamin

\begin{tabular}{clcc}
\hline No & Jenis Kelamin & Jumlah & Persentase \\
\hline 1 & Laki-laki & 29 & $39,2 \%$ \\
2 & Perempuan & 45 & $60,8 \%$ \\
& Jumlah & 74 & $100 \%$ \\
\hline
\end{tabular}

Sumber: Data Kepegawaian Perpustakaan UGM Tahun 2017

Tabel 4. Pustakawan UGM berdasarkan Pendidikan

\begin{tabular}{llrr}
\hline No & Pendidikan & Jumlah (Orang) & Persentase \\
\hline 1 & SLTA & 4 & 5,4 \\
2 & Diploma & 20 & 27 \\
3 & Sarjana (S-1) & 28 & 37,8 \\
4 & Magister(S-2) & 21 & 28,4 \\
5 & Doktor (S-3) & 1 & 1,4 \\
& Total & 74 & 100 \\
\hline \multicolumn{2}{l}{ Sumber: Data Kepegawaian Perpustakaan UGM Tahun 2017}
\end{tabular}

Tabel 5. Pelatihan Pengetahuan Umum

\begin{tabular}{llcc}
\hline No & Frekuensi Pelatihan & Jumlah (Orang) & Persentase (\%) \\
\hline 1 & Lebih dari 5 kali & 19 & 25,7 \\
2 & 4-5 kali & 26 & 35,0 \\
3 & $2-3$ kali & 17 & 22,9 \\
4 & $0-1$ kali & 12 & 16,4 \\
& JUMLAH & 74 & 100 \\
\hline
\end{tabular}


Tabel 6. Pelatihan Kepustakawanan

\begin{tabular}{llcc}
\hline No & Frekuensi Pelatihan & Jumlah (Orang) & Persentase (\%) \\
\hline 1 & Lebih dari 5 kali & 6 & 8,1 \\
2 & $4-5$ kali & 30 & 40,5 \\
3 & $2-3$ kali & 23 & 31,1 \\
4 & $0-1$ kali & 15 & 20,3 \\
5 & JUMLAH & 74 & 100 \\
\hline
\end{tabular}

Tabel 7. Rekapitulasi persentase terbesar dari setiap item pada masing-masing indikator

\begin{tabular}{|c|c|c|c|c|}
\hline Variabel & Indikator & Kategori & $\mathbf{f}$ & $\%$ \\
\hline \multirow[t]{12}{*}{ Kinerja } & 1. Frekuensi pustakawan mengkaji tugas pokok & Kadang-kadang & 35 & 47,3 \\
\hline & $\begin{array}{l}\text { 2. Frekuensi pustakawan mendiskusikan tugas pokok dengan sesama } \\
\text { pustakawan }\end{array}$ & Kadang-kadang & 35 & 47,3 \\
\hline & $\begin{array}{l}\text { 3. Frekuensi pustakawan dalam memberikan tanggapan mengenai tugas } \\
\text { pokok pustakawan }\end{array}$ & Kadang-kadang & 43 & 58,1 \\
\hline & $\begin{array}{l}\text { 4. Frekuensi pustakawan dalam mendiskusikan tugas pokok dan } \\
\text { fungsinya dengan atasannya }\end{array}$ & Kadang-kadang & 52 & 70,3 \\
\hline & $\begin{array}{l}\text { 5. Frekuensi pustakawan dalam mengajukan perubahan tugas pokok pada } \\
\text { saat pembahasan }\end{array}$ & Kadang-kadang & 36 & 48,6 \\
\hline & $\begin{array}{l}\text { 6. Frekuensi pustakawan dalam melakukan dialog langsung dengan } \\
\text { pemustaka yang dilayani }\end{array}$ & Sering & 42 & 56,8 \\
\hline & $\begin{array}{l}\text { 7. Frekuensi pustakawan dalam melakukan kunjungan ke unit lain untuk } \\
\text { memperoleh masukan tentang tugas pokok dan fungsinya }\end{array}$ & Kadang-kadang & 44 & 59,5 \\
\hline & $\begin{array}{l}\text { 8. Frekuensi pustakawan dalam mengajak kerjasama dengan pustakawan } \\
\text { lain/organisasi profesi untuk memperoleh berbagai masukan }\end{array}$ & Kadang-kadang & 49 & 66,2 \\
\hline & $\begin{array}{l}\text { 9. Frekuensi pustakawan dalam menyampaikan aspirasi atau masukan } \\
\text { dari masyarakat/pemustaka dalam berbagai kesempatan atau rapat }\end{array}$ & Sering & 35 & 47,3 \\
\hline & $\begin{array}{l}\text { 10. Frekuensi data tentang peran aktif pustakawan dalam implementasi } \\
\text { penggunaan anggaran yang sudah ditetapkan }\end{array}$ & Kadang-kadang & 37 & 50,0 \\
\hline & $\begin{array}{l}\text { 11. Frekuensi ketepatan waktu pustakawan dalam kenaikan pangkat dan } \\
\text { atau jabatan sesuai ketentuan }\end{array}$ & Kadang-kadang & 44 & 59,5 \\
\hline & 12. Frekuensi pustakawan dalam menghasilkan karya tulis setiap tahunnya & Kadang-kadang & 56 & 75,7 \\
\hline
\end{tabular}

Tabel 8. Interval Kategori Kinerja Pustakawan UGM

\begin{tabular}{cc}
\hline Interval & Kategori \\
\hline $76 \%-100 \%$ & Baik \\
$56 \%-75 \%$ & Cukup \\
$<56 \%$ & Kurang \\
\hline
\end{tabular}


Tabel 9. Korelasi Pendidikan dan Pelatihan dengan Kinerja Pustakawan UGM

\begin{tabular}{|c|c|c|c|c|c|c|c|}
\hline \multirow{3}{*}{ Variabel } & \multicolumn{6}{|c|}{ Kinerja } & \multirow{3}{*}{$\mathrm{P}$} \\
\hline & \multicolumn{2}{|c|}{ Baik } & \multicolumn{2}{|c|}{ Cukup } & \multicolumn{2}{|c|}{ Kurang } & \\
\hline & $\mathrm{F}$ & $\%$ & $\mathrm{~F}$ & $\%$ & $\mathrm{~F}$ & $\%$ & \\
\hline \multicolumn{8}{|c|}{ Pendidikan } \\
\hline SLTA & 0 & 0,0 & 3 & 75,0 & 1 & 25,0 & 0,708 \\
\hline Diploma & 3 & 15,0 & 11 & 55,0 & 6 & 30,0 & \\
\hline S-1 & 2 & 7,1 & 20 & 71,4 & 6 & 21,4 & \\
\hline $\mathrm{S}-2$ & 1 & 4,8 & 15 & 71,4 & 5 & 23,8 & \\
\hline S-3 & 1 & 100,0 & 0 & 0,0 & 0 & 0,0 & \\
\hline \multicolumn{8}{|c|}{ Pelatihan Diluar Bidang Tugas } \\
\hline$>5$ kali & 1 & 5,3 & 13 & 68,4 & 5 & 26,3 & 0,005 \\
\hline $4-5$ kali & 1 & 3,8 & 13 & 50,0 & 12 & 46,2 & \\
\hline $2-3$ kali & 2 & 11,8 & 14 & 82,4 & 1 & 5,9 & \\
\hline 0-1 kali & 3 & 25,0 & 9 & 75,0 & 0 & 0,0 & \\
\hline \multicolumn{8}{|c|}{ Pelatihan Sesuai Bidang Tugas } \\
\hline$>5$ kali & 0 & 0,0 & 5 & 83,3 & 1 & 16,7 & 0,143 \\
\hline $4-5$ kali & 2 & 6,7 & 19 & 63,3 & 9 & 30,0 & \\
\hline $2-3$ kali & 1 & 4,3 & 16 & 69,6 & 6 & 26,1 & \\
\hline 0-1 kali & 4 & 26,7 & 9 & 60,0 & 2 & 13,3 & \\
\hline
\end{tabular}

